\title{
Quality of Kikuyu herbage from pastures in the Eastern Cape coastal belt of South Africa
}

\author{
N. Miles ${ }^{1}$, L. Thurtell and S. Riekert \\ KwaZulu-Natal Department of Agriculture \& Environmental Affairs \\ e-mail: ${ }^{1}$ milesn@dae.kzntl.gov.za
}

\section{Introduction}

Kikuyu grass (Pennisetum clandestinum Hochst) is of major importance as a pasture species in Southern Africa. The high yield potential, resilience under poor management and favourable response to $\mathrm{N}$ fertilizers are among the factors accounting for the widespread use of this grass. Kikuyu is, however, not without its limitations, and questions surround its quality in terms of the nutritional requirements of high-producing dairy cows. Reduced palatability with consequent poor intake and poor animal production, as well as bloat, milk fever and infertility are problems sporadically encountered on kikuyu pastures. This paper deals with a detailed survey of the quality of kikuyu herbage from farms on the Eastern Cape coastal belt of South Africa.

\section{Materials and Methods}

Herbage samples were taken at monthly intervals from six farms on the coastal belt south of Alexandria in the Eastern Cape of South Africa (all farms are located within $3 \mathrm{~km}$ of the sea). Sampling was during the period November 1997 to December 1999. Pastures were rotationally-grazed by high-producing dairy herds and received regular dressings of $\mathrm{N}$ fertilizer, with total annual fertilizer $\mathrm{N}$ rates ranging from 200 to $600 \mathrm{~kg} \mathrm{ha}^{-1} \mathrm{yr}^{-1}$. Herbage samples were taken by "plucking", with the intention being to simulate the grazing process. Samples were ovendried and analysed for minerals and other quality components.

\section{Results and Discussion}

The mean mineral concentrations and the ranges measured in samples from the six farms are presented in Table 1.

Table 1 Mean mineral concentrations (dry matter basis) of kikuyu herbage from Eastern Cape farms and dietary mineral requirements of high-producing dairy cows.

\begin{tabular}{cccc}
\hline Element & Mean & E. Cape kikuyu & \\
$\mathrm{Ca}(\%)$ & 0.48 & $0.27-0.85$ & Cow requirements* \\
$\mathrm{P}(\%)$ & 0.40 & $0.18-0.64$ & $0.4-0.5$ \\
$\mathrm{Ca}: \mathrm{P}$ & 1.30 & $0.61-3.27$ & $0.3-0.4$ \\
$\mathrm{~K}(\%)$ & 3.40 & $0.69-5.51$ & 0.9 \\
$\mathrm{Mg}(\%)$ & 0.36 & $0.19-0.71$ & 0.2 \\
$\mathrm{Na}(\%)$ & 0.24 & $0.06-0.61$ & 0.12 \\
$\mathrm{~S}(\%)$ & 0.27 & $0.19-0.35$ & 0.12 \\
$\mathrm{Zn}\left(\mathrm{mg} \mathrm{kg}^{-1}\right)$ & 35.6 & $11-94$ & 26 \\
$\mathrm{Cu}\left(\mathrm{mg} \mathrm{kg}^{-1}\right)$ & 6.0 & $2-15$ & 10 \\
$\mathrm{Mn}\left(\mathrm{mg} \mathrm{kg}^{-1}\right)$ & 67.5 & $25-171$ & 25 \\
\hline
\end{tabular}

*Holmes \& Wilson, 1987; NRC, 1989

Concentrations of all the minerals considered generally exceeded or matched cow requirements, with the exception of $\mathrm{Cu}$, which had a mean concentration of $6 \mathrm{mg} \mathrm{kg}^{-1}$ (cow requirements $10 \mathrm{mg} \mathrm{kg}^{-1}$ ). Particularly noteworthy are the relatively high $\mathrm{Ca}$ concentrations and favourable $\mathrm{Ca}: \mathrm{P}$ ratio in the kikuyu. Calcium concentrations in kikuyu growing in Queensland, Australia, were reported to be in the range 0.29 to $0.31 \%$ (Reason et al., 1989). Kikuyu growing on various sites in the KwaZulu-Natal Midlands was found to have average Ca concentrations ranging from 0.23 to $0.31 \%$, while the $\mathrm{Ca}: \mathrm{P}$ ratio was in the range 0.68 to 0.95 (Miles et al., 1995). The availability to animals of $\mathrm{Ca}$ in kikuyu is reported to be severely restricted by the high oxalate levels in this grass (Marais, 1990); however, preliminary measurements (data not reported) on oxalate concentrations in the Eastern Cape kikuyu indicate relatively low oxalate concentrations. As is frequently the case in pasture herbage, $\mathrm{K}$ 
Short paper and poster abstracts: $38^{\text {th }}$ Congress of the South African Society of Animal Science

levels were well in excess of animal requirements, with concentrations of up to $5.51 \%$ being recorded. The NRC (1989) reports a "maximum tolerable" K concentration in the diets of dairy cows and sheep of 3.0\%. Uptake of K by kikuyu has been shown to be closely related to $\mathrm{N}$ supply (Miles et al.,1995), and there is clearly a need, therefore, for judicious use of both $\mathrm{N}$ and $\mathrm{K}$ fertilizers on these pastures. The mean Na concentration of $0.24 \%$ is considerably higher than that measured in KwaZulu-Natal kikuyu, where concentrations ranged from 0.02 to $0.05 \%$. Surface contamination with sea spray is thought to account for the higher Na levels in the kikuyu from the Eastern Cape.

Table 2 Nitrogen fractions, neutral detergent fiber (NDF), acid detergent fibre (ADF), non-structural carbohydrates (NSC) and fat in Eastern Cape kikuyu herbage (data on dry matter basis).

\begin{tabular}{|c|c|c|c|c|c|c|c|c|}
\hline & $\begin{array}{l}\text { Protein } \\
\text { (crude) }\end{array}$ & $\begin{array}{c}\text { Non- } \\
\text { protein } \mathrm{N}\end{array}$ & Nitrate-N & $\mathrm{NDF}$ & $\mathrm{ADF}$ & $\mathrm{NSC}$ & $\begin{array}{c}\text { Protein:N } \\
\text { SC }\end{array}$ & Fat \\
\hline Mean & 21.06 & 6.18 & 0.08 & 63.1 & 29.7 & 3.87 & 6.31 & 2.76 \\
\hline Range & $8.31-33.33$ & $0.43-14.33$ & $0.01-0.24$ & $42.3-84.0$ & $20.2-42.0$ & $1.04-9.18$ & $1.2-26.9$ & $0.56-5.81$ \\
\hline
\end{tabular}

Measures of various additional components related to nutritive value are presented in Table 2. In unpublished research by the senior author, it was found that the critical $\mathrm{N}$ concentration for maximum growth of kikuyu is approximately $2.8 \%$, with this being equivalent to $17.5 \%$ crude protein. The mean protein content of the kikuyu was $21.06 \%$, and it would appear that in general, $\mathrm{N}$ supply was therefore adequate for growth. However, the wide range in protein contents point to periods of excessive and insufficient $\mathrm{N}$ supply. Nitrate- $\mathrm{N}$ concentrations were low in terms of toxicity thresholds for dairy cows (Eckard \& Dugmore,1994). Relative to most temperate grasses, the nonstructural carbohydrate (NSC) content of the kikuyu was extremely low. In studies undertaken in New South Wales, Fulkerson et al. (1998), too, drew attention to the problem of low NSC levels in kikuyu, and they point out that the high ratio of protein:NSC is a major limiting factor in animal production on kikuyu pastures. The acid detergent fibre (ADF) level of $29.7 \%$ is appreciably higher than the recommended $21 \%$ in the ration of cows producing between 20 and 30 litres of milk per day (NRC, 1989). The mean neutral detergent fibre (NDF) content was $63.1 \%$, with values for this component being lowest in the winter months. In the studies of Fulkerson et al. (1998), the mean NDF in summer was $60 \%$ and in winter $40 \%$.

\section{Conclusions}

The kikuyu growing on the Eastern Cape coastal belt has a higher Ca content and a resultant more favourable $\mathrm{Ca}: \mathrm{P}$ ratio than that in other parts of South Africa and Australia. Excessive $\mathrm{K}$ and fibre, insufficient $\mathrm{Cu}$, and extremely low NSC concentrations are major limiting factors in terms of the nutritive value of the grass.

\section{References}

Eckard, R. J. \& Dugmore, T. J., 1994. Cedara Report No. N/A/94/3. Cedara Agricultural Development Institute. Holmes, C. W. \& Wilson, G. F., 1987. Milk Production from Pasture. Butterworths, Wellington.

Fulkerson, W. J. et al., 1998. Aust. J. Exp. Agric. 38, 227.

Marais, J P., 1990. J. Grassld Soc. S. A. 7, 106.

Miles, N. et al., 1995. J. S. Afr. Vet. Ass. 66, 206-212.

NRC. 1989. Nutrient Requirements of Dairy Cattle. $6^{\text {th }}$ Rev. Edn. National Academic Press, Washington, DC.

Reason, G. K., et al., 1989. Recent Advances in Animal Nutrition in Australia. University of New England, Armidale. 